\title{
Measurement of Nucleoside Kinases in Crude Tissue Extracts ${ }^{1}$
}

\author{
Mary C. Hurley and Irving H. Fox ${ }^{2}$ \\ Human Purine Research Center, Departments of Internal Medicine and Biological \\ Chemistry, Clinical Research Center, University of Michigan, Ann Arbor, \\ Michigan 48109
}

Received November 10, 1982

Adenosine, deoxyadenosine, and deoxycytidine can be phosphorylated to their respective nucleoside $5^{\prime}$-monophosphates by kinase enzymes. In addition to their physiological role of salvaging nucleosides to form nucleotides, these enzymes are critical for the increased intracellular concentration of dATP associated with a deficiency of adenosine deaminase $(1,2)$. These enzymes also phosphorylate nucleoside analogs that have antineoplastic or antiviral properties.

The development of relatively simple assays, using high specific activity isotopes and anion exchange paper (3), has allowed extensive investigation of nucleoside kinases. During our studies of placental nucleoside kinases we used previously developed assay conditions (3-5) including uniformly labeled substrates (6-8). However, we could not achieve linearity with time or protein.

To develop valid methods for these assays, we had to systematically investigate specific problems related to the measurement of adenosine kinase (ATP: adenosine 5'-phosphotransferase, EC2.7.1.20), deoxyadenosine kinase (ATP: deoxyadenosine 5'-phosphotransferase EC2.7.1.76), and deoxycytidine kinase (NTP: deoxycytidine 5'-phosphotransferase, EC2.7.1.74) in placental cytosol. Our observations suggest the following conditions are important for the assay of kinase enzymes in crude preparations: (a) the addition of potassium cation for deoxyadenosine and adenosine kinases, (b) the addition of a sulfhydryl reducing reagent, and (c) the substitution of GTP for ATP as the phosphate donor for deoxyadenosine kinase and adenosine kinase. Our observations also confirm

' This work was generously supported by USPHS Grant AM 19674 and 5 MO1 RR 42.

${ }^{2}$ To whom requests for reprints should be addressed: Clinical Research Center, W4642 University of Michigan Hospital, Ann Arbor, Michigan 48109. 
that deaminase inhibitors are essential to prevent substrate degradation (9-15).

\section{MATERIALS AND METHODS}

\section{Materials}

The following reagents were obtained from Sigma Chemical Company, St. Louis, Missouri: Bials reagent, Trizma Base, $\beta$-mercaptoethanol. dithiothreitol, adenosine, deoxyadenosine, deoxycytidine, adenosine 5'triphosphate, guanosine 5'-triphosphate, bovine serum albumin, deoxyribose 1-phosphate and deoxyribose 5-phosphate. The following were obtained from Amersham Corporation, Arlington Heights. Illinois: [8$\left.{ }^{14} \mathrm{C}\right] \mathrm{ATP}(1.03 \mathrm{mCi} / \mathrm{mmole})$, [U- ${ }^{14} \mathrm{C}$ ]deoxyadenosine $(536 \mathrm{mCi} / \mathrm{mmole})$. $\left[\mathrm{U}-{ }^{14} \mathrm{C}\right]$ deoxycytidine $(462 \mathrm{mCi} / \mathrm{mmole})$, and ACS scintillation cocktail. From ICN Pharmaceuticals, Inc., Irvine, California, $\left[8-{ }^{3} \mathrm{H}\right]$ deoxyadenosine $(15 \mathrm{Ci} / \mathrm{mmole})$ and $\left[5-{ }^{3} \mathrm{H}\right]$ deoxycytidine $(25 \mathrm{Ci} / \mathrm{mmole})$ were obtained. New England Nuclear, Boston, Massachusetts was the source for $\left[8-{ }^{14} \mathrm{C}\right]$ adenosine $(54$ or $45 \mathrm{mCi} / \mathrm{mmole}$ ). Tetrahydrouridine, a cytidine deaminase inhibitor. was obtained from Calbiochem-Behring, La Jolla. California. DE-81 ion exchange disks and Whatman 3MM chromatography paper were purchased from Fisher Scientific Company, Fair Lawn, New Jersey. Bio-Rad protein dye reagent concentrate was obtained from BioRad Laboratories, Richmond, California. Erythro-9-(2-hydroxyl-3nonyl)adenine (EHNA), an adenosine deaminase inhibitor, was purchased from Burroughs Wellcome Company, Research Triangle Park, North Carolina. The drug 2'-deoxycoformycin, another adenosine deaminase inhibitor, was a gift from Warner Lambert/Parker Davis. Ann Arbor. Michigan. All other reagents were of the highest quality generally obtainable.

\section{Placenta Preparation}

Human placentae were processed within $8 \mathrm{hr}$ of delivery. Prior to processing the placental membranes were discarded and the remaining tissue was blotted on gauze, weighed, and then coursely minced. The minced tissue was suspended in $10 \mathrm{~mm} \beta$-mercaptoethanol and $10 \mathrm{~mm}$ imidazole- $\mathrm{HCl}, \mathrm{pH} 7.0(1 \mathrm{~g}$ tissue $/ 4.3 \mathrm{ml})$ and then homogenized using a Sorval Omni-mixer at maximum speed for four periods of $30 \mathrm{sec}$ each. The homogenate was spun at $28,000 \mathrm{~g}$ for $1 \mathrm{hr}$ at $4^{\circ} \mathrm{C}$ in a Sorval refrigerated centrifuge and the resulting supernatant was stored at $-70^{\circ} \mathrm{C}$. This extract was usually dialyzed for $16 \mathrm{hr}$ against $10 \mathrm{~mm} \beta$-mercaptoethanol and 10 $\mathrm{mm}$ Tris- $\mathrm{HCl}, \mathrm{pH} 7.0$, prior to enzyme assay.

\section{Separation Methods}

A number of methods were used to separate substrates and products of the reactions. Nucleosides were separated from nucleotides by spotting 
20- $\mu$ l aliquots of incubation extracts onto DE-81 disks (3) or onto Whatman $3 \mathrm{MM}$ chromatography sheets. The chromatography sheets were also spotted with authentic nucleoside substrate and nucleotide product (1 $\mathrm{mg} / \mathrm{ml}$ ). The disks were washed twice for $5 \mathrm{~min}$ with $1 \mathrm{~mm}$ ammonium formate, and subsequently washed twice with water and once with $95 \%$ ethanol. With tritiated isotopes the disks were placed into scintillation vials with $0.5 \mathrm{ml}$ of $0.1 \mathrm{~N} \mathrm{HCl}$ and $0.4 \mathrm{M} \mathrm{KCl}$ to elute the radioactive nucleotide products (3) and were counted in $5 \mathrm{ml} \mathrm{ACS}$. High voltage electrophoresis was performed with either $50 \mathrm{~mm}$ sodium borate, $\mathrm{pH} 8.9$, or $50 \mathrm{~mm}$ sodium citrate, $\mathrm{pH} 3.5$. High voltage electrophoresis in borate buffer was run at 4000 Volts and $250 \mathrm{~mA}$ for $30 \mathrm{~min}$ or in citrate buffer at 2000 Volts and $100 \mathrm{~mA}$ for $60 \mathrm{~min}$. The carrier compounds were located using an ultraviolet light. The migration of relevant compounds was determined in these two buffer systems (Table 1). The spots were cut out and counted in a liquid scintillation spectrometer system.

Radioactive deoxyribose-1-phosphate was separated from purine or pyrimidine compounds in the heat-inactivated reaction mixtures by the addition of an equal volume of a $10 \%$ charcoal solution. Deoxyribose1-phosphate does not bind to charcoal and remains in the supernatant, while all purine and pyrimidine compounds are removed by the charcoal. Ribose- or deoxyribose-containing compounds were detected by using a spray containing Bials reagent $(0.9 \%$ ferric chloride and $0.55 \%$ orcinol in acidified ethanol).

TABLE 1

Relative Migration of Nucleosides and Nucleotides on High Voltage ELECTROPHORESIS

\begin{tabular}{|c|c|c|}
\hline \multirow[b]{2}{*}{ Compound } & \multicolumn{2}{|c|}{ Centimeters migrated } \\
\hline & Sodium borate & Sodium citrate ${ }^{b}$ \\
\hline Adenosine & 9 & - \\
\hline Deoxyadenosine & $(-) 2^{\prime}$ & - \\
\hline Inosine & 16 & - \\
\hline Deoxyinosine & 3 & - \\
\hline Deoxycytidine & - & $(-) 3$ \\
\hline Deoxyuridine & - & 2 \\
\hline AMP & 25 & - \\
\hline dAMP & 11 & - \\
\hline dIMP & 12 & - \\
\hline $\mathrm{dCMP}$ & - & 7 \\
\hline dUMP & - & 14 \\
\hline Deoxyribose-1-P & 11 & - \\
\hline
\end{tabular}

" $50 \mathrm{~mm}$ Sodium borate, $\mathrm{pH} 8.9$, run at $4000 \mathrm{~V}$ and $250 \mathrm{~mA}$ for $20 \mathrm{~min}$.

" $50 \mathrm{~mm}$ Sodium citrate, $\mathrm{pH} 3.5$, run at $2000 \mathrm{~V}$ and $100 \mathrm{~mA}$ for $60 \mathrm{~min}$.

' $(-)$ Refers to migration below the application line. 


\section{Assays}

Assay conditions were devised to give linearity with time and protein. The final conditions used represent a combination of our previous work $(4.5)$, the reports of others $(9-15)$ and our current observations. Adenosine kinase and deoxyadenosine kinase were assayed as follows: $50 \mathrm{~mm}$ Tris$\mathrm{HCl}, \mathrm{pH} 7.4,1.2 \mathrm{~mm}$ GTP, $1.6 \mathrm{~mm} \mathrm{MgCl}_{2}, 50 \mathrm{~mm} \mathrm{KCl}, 50 \mathrm{~mm} \beta$-mercaptoethanol, $1 \mathrm{mg} / \mathrm{ml}$ bovine serum albumen, $50 \mu \mathrm{M}$ EHNA. and $10 \mu \mathrm{m}$ $\left[8-{ }^{14} \mathrm{C}\right]$ adenosine or $500 \mu \mathrm{M}\left[8-{ }^{3} \mathrm{H}\right]$ deoxyadenosine in a total volume of $50 \mu \mathrm{l}$. Deoxycytidine kinase was assayed as follows: $50 \mathrm{~mm}$ Tris- $\mathrm{HCl}$ $\mathrm{pH} 8.0,2.0 \mathrm{~mm}$ ATP, $2.4 \mathrm{~mm} \mathrm{MgCl}, 25 \mathrm{~mm}$ dithiothreitol, $125 \mu \mathrm{M}$ tetrahydrouridine, $1 \mathrm{mg} / \mathrm{ml}$ bovine serum albumen, and $10 \mu \mathrm{M} 15-$ ${ }^{3} \mathrm{H}$ ]deoxycytidine in a total volume of $50 \mu \mathrm{l}$. Adjustments of other components of the assays are described under results. The following incubation periods at $37^{\circ} \mathrm{C}$ were used: deoxyadenosine kinase, $20 \mathrm{~min}$; deoxycytidine kinase, 20 min: adenosine kinase, $5 \mathrm{~min}$. The assays were stopped by heat inactivation at $85^{\circ} \mathrm{C}$ for $2 \mathrm{~min}$. Isolation of nucleotide product was performed using DE-81 disks as described above. The formation of specific nucleotide product was confirmed using comigration with the authentic compound during high voltage electrophoresis. Comigration with the nucleoside di- and triphosphate derivatives was also examined. The assays were linear with time and protein.

The formation of adenosine from ATP degradation during the assays of adenosine kinase or deoxyadenosine kinase was measured in two ways. In one series of studies, $1.2 \mathrm{~mm}\left[8{ }^{14} \mathrm{C}\right] \mathrm{ATP}$ was used and the formation of $\left[8-{ }^{14} \mathrm{C}\right]$ adenosine was measured after its separation with high voltage electrophoresis in borate buffer. In another series of studies no isotope was used and adenosine formation from ATP was measured by high-pressure liquid chromatography using a Waters $\mu$ Bondapak $\mathrm{C}_{18}$ column and isocratic elution of adenosine by $50 \mathrm{~mm}$ ammonium phosphate, $\mathrm{pH}$ 6.0 , in $5 \%$ methanol. Using a flow rate of $2 \mathrm{ml} / \mathrm{min}$ adenosine eluted at $15 \mathrm{~min}$.

Protein was estimated using the Bio-Rad assay method with bovine serum albumin as the standard protein (16).

\section{RESULTS}

\section{Deaminase Inhibition}

In our initial assays of deoxyadenosine kinase and deoxycytidine kinase. we followed previously published procedures (3-8). These conditions included the following: ATP as phosphate donor, no addition of potassium or sulfhydryl reducing compound, $500 \mu \mathrm{M}\left[\mathrm{U}-{ }^{14} \mathrm{C}\right]$ deoxyadenosine or $\left[\mathrm{U}-{ }^{14} \mathrm{C}\right]$ deoxycytidine, and DE-81 disks for product isolation. With these assay conditions we were unable to establish linearity with time and protein for deoxyadenosine kinase or deoxycytidine kinase. Furthermore. 
the addition of $50 \mu \mathrm{M}$ EHNA or deoxycoformycin caused apparent inhibition of deoxyadenosine kinase. This was puzzling because previous studies had indicated the importance of blocking adenosine deaminase or cytidine deaminase during the measurement of kinase activity in order to prevent substrate degradation (9-15). With the uniformly labeled substrates we were able to demonstrate that half of the product being measured with the initial assay conditions was deoxyribose-1-phosphate (Table 2). This latter compound behaved exactly like a nucleotide on the DE-81 disks or during high voltage electrophoresis, which was confirmed by using authentic deoxyribose-1-phosphate. The radioactively labeled deoxyribose1-phosphate was distinguished from radioactivity labeled purines or pyrimidines by its property of not binding to charcoal. Deoxyribose-1phosphate remained in the supernatant following charcoal extraction of reaction mixtures. The increased formation of nucleotide product and the decreased synthesis of deoxyribose-1-phosphate was evident in the assay of deoxyadenosine kinase under conditions which optimize the assay method (Table 2). In a similar study with deoxycytidine kinase, we observed 2.4 nmole deoxyribose-1-phosphate and 0.2 nmole nucleotide formed after a 30 -min incubation period using initial assay conditions plus $50 \mathrm{~mm} \beta$-mercaptoethanol. This problem was similarly modified using the optimized conditions described below.

The source of inorganic phosphate to serve as substrate for the phosphorolysis reactions in dialyzed placental cytosol was initially unclear. However, when we calculated the amount of inorganic phosphate generated from the dephosphorylation of triphosphate substrate, we found that there was a sufficient amount to permit these reactions.

TABLE 2

Formation of Deoxyribose-1-phosphate during Assay of Deoxyadenosine Kinase

Additions to assay

\begin{tabular}{cccc}
$\begin{array}{c}\text { Albumin (bovine } \\
\text { serum, } 1 \mathrm{mg} / \mathrm{ml}), \\
\mathrm{KCl}(50 \mathrm{mM}), \beta- \\
\begin{array}{c}\text { mercaptoethanol } \\
(50 \mathrm{~mm})\end{array}\end{array}$ & $\begin{array}{c}\text { Deoxycoformycin } \\
(50 \mu \mathrm{M})\end{array}$ & $\begin{array}{c}\text { Deoxyribose-1- } \\
\text { phosphate }\end{array}$ & $\begin{array}{c}\text { Nucleotide } \\
\text { product }^{h}\end{array}$ \\
\hline- & - & 0.16 & 0.14 \\
+ & - & 0.14 & 0.15 \\
- & + & 0 & 0.12 \\
+ & + & 0.05 & 0.11 \\
+ & + & 0.06 & $0.40^{\prime \prime}$
\end{tabular}

Note. All assays contained $0.2 \mathrm{mg}$ placental protein extract, $1.2 \mathrm{~mm} \mathrm{ATP}, 1.6 \mathrm{mM} \mathrm{MgCl}$, $50 \mathrm{~mm}$ Tris- $\mathrm{HCl}, \mathrm{pH} 7.4$, and $500 \mu \mathrm{M}\left[\mathrm{U}-{ }^{14} \mathrm{C}\right]$ deoxyadenosine and were incubated at $37^{\circ} \mathrm{C}$ for 30 min.

" $1.2 \mathrm{~mm}$ GTP was substituted for $1.2 \mathrm{~mm}$ ATP.

" $\mathrm{nmol} / 50 \mu \mathrm{l}$ reaction mixture. 
A. Deoxyadenosinc

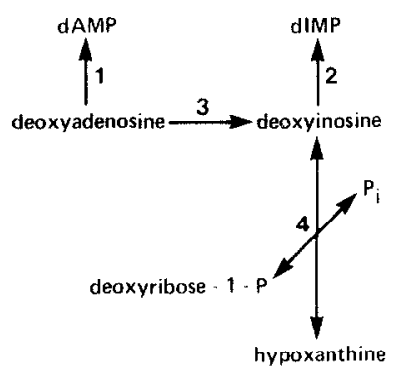

B. Deoxycytidine

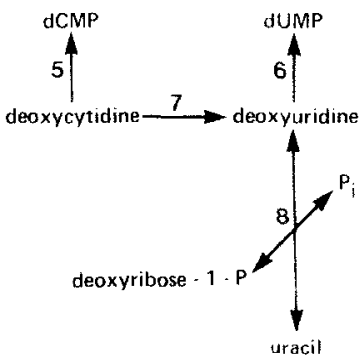

FIG. 1. Metabolic interconversions of deoxyadenosine and deoxycylidine. (A) Deoxyadenosine is deaminated to deoxyinosine (reaction 3). Both compounds may be phosphorylated (reactions 1 and 2). Deoxyinosine undergoes phosphorolysis to hypoxanthine and deoxyribose1-phosphate (reaction 4), (B) Deoxycytidine is deaminated to deoxyuridine (reaction 7). Both compounds may be phosphorylated (reactions 5 and 6). Deoxyuridine undergoes phosphorolysis to deoxyribose-1-phosphate and uracil (reaction 8). With uniformly labeled isotopes all these intermediates are radioactively labeled.

The extensive substrate deamination observed, together with the subsequent phosphorolysis or phosphorylation of the resulting degradation products (Fig. 1), emphasizes that product identification is essential. For example, in the deoxycytidine kinase assay, all the deoxcytidine is deaminated to deoxyuridine and deoxyuridine kinase was actually measured unless cytidine deaminase was inhibited (Table 3). The addition of an adenosine deaminase inhibitor was also important in protecting against the degradation of deoxyadenosine to deoxyinosine (Table 4). In addition,

TABLE 3

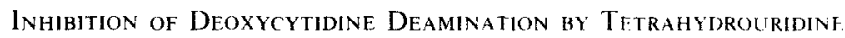

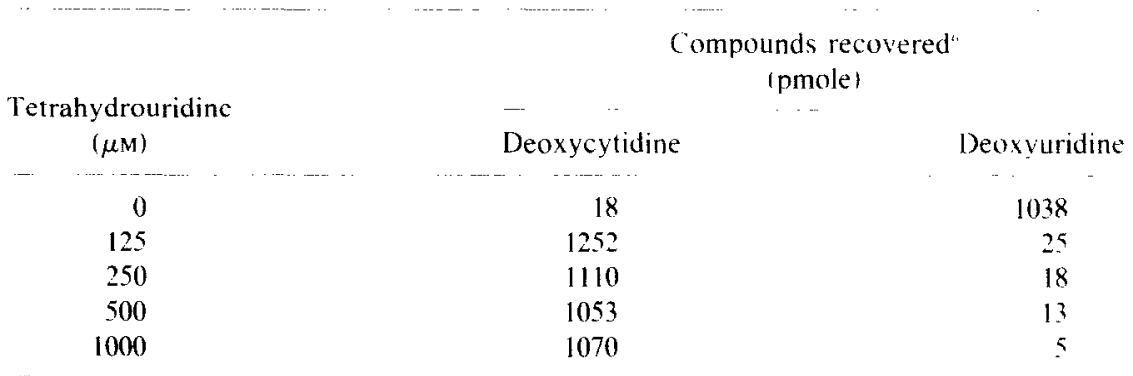

Note. Placental cytosol was preincubated for $60 \mathrm{~min}$ with tetrahydrouridine. Placental cytosol (40 $\mu \mathrm{g}$ protein) was then incubated with $20 \mu \mathrm{M}\left[5-{ }^{3} \mathrm{H}\right]$ deoxycytidine. $100 \mathrm{~mm}$ Tris-

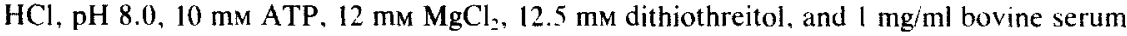
albumin for $30 \mathrm{~min}$. The compounds were separated by high voltage electrophoresis in 50 mm sodium citrate $\mathrm{pH} 3.5$.

" pmole/50 $\mu$ l reaction mixture. 
TABLE 4

Inhibition of Dexyadenosine Deamination by EHNA in Placental Supernatant

\begin{tabular}{|c|c|c|}
\hline \multirow{2}{*}{$\begin{array}{l}\text { EHNA" } \\
\quad(\mu \mathrm{M})\end{array}$} & \multicolumn{2}{|c|}{ Compounds recovered (nmole) $)^{h}$} \\
\hline & Deoxyinosine & Deoxyadenosine \\
\hline 0 . & 8 & 14 \\
\hline 0.05 & 9 & 17 \\
\hline 0.50 & 4 & 20 \\
\hline 5.00 & 0.6 & 25 \\
\hline 50.00 & 0 & 25 \\
\hline
\end{tabular}

"EHNA, erythro-9-(2-hydroxyl-3-nonyl)adenine.

${ }^{t}$ nmole $/ 50 \mu$ l reaction mixture.

Assays were performed with $400 \mu \mathrm{g}$ placental supernatant, $1.2 \mathrm{~mm}$ ATP, $1.6 \mathrm{~mm} \mathrm{MgCl}_{2}$. $0.5 \mathrm{~mm}\left[\mathrm{U}-{ }^{14} \mathrm{C}\right]$ deoxyadenosine, and $50 \mathrm{~mm}$ Tris- $\mathrm{HCl}, \mathrm{pH} 7.4$.

our studies in placental cytosol revealed that the major product formed under valid assay conditions was frequently the nucleoside triphosphate, an occurance also previously reported (11).

These observations support the importance of blocking nucleoside substrate degradation by deaminase inhibitors as has been done by a number of investigators (9-15).

\section{Phosphate Donor}

The degradation of the phosphate donor substrate has been observed by some investigators, who have used ATP regeneration systems for assays of crude extracts $(9,14,17-22)$. While we have observed some degradation of ATP, the ATP concentration remained saturating.

In our experiments GTP was substituted for ATP. GTP is as efficient as ATP in phosphorylating certain nucleosides $(8,23,24)$. Both adenosine kinase and deoxyadenosine kinase exhibited more than a twofold increase in activity following the substitution of GTP (Fig. 2. Table 5). Two mechanisms could account for this observation: (a) ATP is degraded to adenosine, which then inhibits enzyme activity, or (b) GTP is a preferred phosphate donor.

Under optimized conditions of the adenosine kinase assay no adenosine accumulation from ATP was detected using $\left[8-{ }^{14} \mathrm{C}\right]$ adenosine release from $\left[8-{ }^{14} \mathrm{C}\right] \mathrm{ATP}$ or high-pressure liquid chromatography. This supports the mechanism (b) above, which agrees with our observations and other studies $(22,25,26)$ in highly purified adenosine kinase.

In contrast, the optimized conditions of the deoxyadenosine kinase assay yielded a 2 to $3 \mu \mathrm{M}$ accumulation of adenosine from ATP. In order to assess the effect of adenosine on the deoxyadenosine kinase reaction, up to $10 \mu \mathrm{M}$ adenosine was added to the assay. Ten micromolar adenosine 


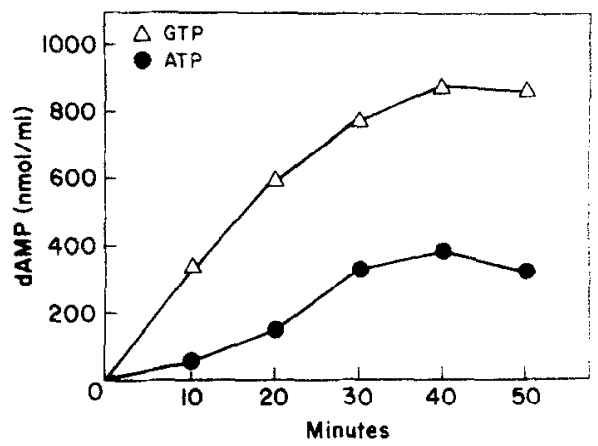

Fig. 2. Time course of deoxyadenosine kinase activity in human placental supernatant. Protein extract $(200 \mu \mathrm{g})$ was incubated with $50 \mathrm{~mm}$ Tris $-\mathrm{HCl}, \mathrm{pH} 7.4,50 \mathrm{~mm} \mathrm{KCl}, 50 \mathrm{~mm}$ $\beta$-mercaptoethanol, $1 \mathrm{mg} / \mathrm{ml}$ bovine serum albumen, $50 \mu \mathrm{M}$ deoxycoformycin, and $1.2 \mathrm{~mm}$ ATP or GTP in a total volume of $50 \mu \mathrm{l}$ at $37^{\circ} \mathrm{C}$. Under these conditions linearity with time is evident up to $20 \mathrm{~min}$ with GTP as phosphate donor.

inhibited deoxyadenosine kinase activity by $60 \%$. However, by adding $10 \mu \mathrm{M}\left[8-{ }^{14} \mathrm{C}\right]$ adenosine to the deoxyadenosine kinase reaction mixture, it was shown that all the adenosine disappeared and was converted to nucleotide at the end of the assay period. It appears that a substantial amount of ATP degradation to adenosine must occur during the deoxyadenosine kinase assay to result in the 2 to $3 \mu \mathrm{m}$ adenosine observed at the end of the incubation period. These data support the concept that ATP degradation to adenosine inhibits deoxyadenosine kinase during its assay in placental cytosol. This proposal was supported by our observation that in partially purified enzyme preparations ATP is only slightly superior to GTP as a phosphate donor for deoxyadenosine kinase.

Substitution of GTP for ATP was not useful for deoxycytidine kinase. since this decreased its activity in placental cytosol by about $50 \%$.

TABLE 5

Comparison of ATP and GTP as Phosphate Donors for adenosine Kinase in Human Placental Cytosol.

\begin{tabular}{ccc}
$\begin{array}{c}\text { Phosphate } \\
\text { donor }\end{array}$ & Enzyme specific activity $(\mathbf{n m o l e} / \mathrm{hr} / \mathrm{mg})$ \\
\hline ATP & 29 & deoxycoformycin $(50 \mu \mathrm{M})$ \\
GTP & 59 & 33 \\
\hline
\end{tabular}

Note. Placental cytosol $(10 \mu \mathrm{g})$ was incubated with $10 \mu \mathrm{M}\left[8-{ }^{i+} \mathrm{C}\right]$ adenosine, $1.2 \mathrm{~mm}$ ATP or GTP, $1.6 \mathrm{mM} \mathrm{MgCl}_{2}, 1 \mathrm{mg} / \mathrm{ml}$ bovine serum albumen. $50 \mathrm{~mm} \beta$-mercaptoethanol. and $50 \mathrm{~mm} \mathrm{KCl}$ for $5 \mathrm{~min}$ at $37^{\circ} \mathrm{C}$. 


\section{Monovalent Cation}

The addition of a monovalent cation is important for the measurement of adenosine kinase, while potassium is an absolute requirement for the measurement of deoxyadenosine kinase (Table 6). In the adenosine kinase assay sodium appeared equally capable of activating the reaction and lithium was more effective than either potassium or sodium. In the deoxyadenosine assay neither sodium nor lithium could activate the enzyme.

Deoxycytidine kinase activity was not altered by monovalent cations (Table 6).

\section{Thiol Reagents}

The addition of either $\beta$-mercaptoethanol or dithiothreitol is critical for the deoxycytidine kinase assay. In fact, unless tissue extracts were prepared with $10 \mathrm{~mm} \beta$-mercaptoethanol, no deoxycytidine kinase could be measured. This is in accord with previous observations (12).

The activity of adenosine kinase and deoxyadenosine kinase was enhanced by $\beta$-mercaptoethanol (Table 7 ). We routinely prepare our placental cytosol with $10 \mathrm{~mm} \beta$-mercaptoethanol, since it is essential for the stability of deoxycytidine kinase and does not change the stability of adenosine or deoxyadenosine kinase.

\section{DISCUSSION}

The assays of nucleoside kinases have attracted attention recently because these enzymes have an important relationship to enzyme defi-

TABLE 6

EFFeCt of $\mathrm{KCl}$ on NuCleoside Kinase Enzymes"

\begin{tabular}{rccc}
\hline $\begin{array}{c}\text { KCl } \\
(\mathrm{mM})\end{array}$ & $\begin{array}{c}\text { Deoxycytidine } \\
\text { kinase }^{b}\end{array}$ & $\begin{array}{c}\text { Adenosine } \\
\text { kinase }^{h}\end{array}$ & $\begin{array}{c}\text { Deoxyadenosine } \\
\text { kinase }^{h}\end{array}$ \\
\hline 0 & 0.4 & 27 & 0 \\
2 & - & 34 & 3 \\
4 & - & 38 & 3 \\
8 & - & 38 & 4 \\
16 & - & 49 & 6 \\
25 & 0.4 & - & - \\
32 & - & 52 & - \\
50 & 0.4 & - & 7 \\
64 & - & - & 6 \\
100 & 0.3 & 76 & 6 \\
128 & - & & 7 \\
\hline
\end{tabular}

“All assays included $25 \mathrm{~mm} \beta$-mercaptoethanol.

${ }^{b}$ Enzyme activity expressed in $\mathrm{nmole} / \mathrm{hr} / \mathrm{mg}$. 
TABLE ?

EFFECT OF $\beta$-MERCAPTOETHANOL ON NUClfoside KINASI ENZYMES

\begin{tabular}{|c|c|c|c|c|}
\hline \multirow[b]{2}{*}{$\begin{array}{l}\beta \text {-Mercaptoethanol } \\
\text { (mM) }\end{array}$} & \multicolumn{2}{|c|}{ Adenosine kinase } & \multicolumn{2}{|c|}{ Deoxyadenosine kinase" } \\
\hline & $\begin{array}{c}\text { No } \\
\text { addition }\end{array}$ & $\begin{array}{c}\mathrm{KCl} \\
150 \mathrm{~mm})\end{array}$ & $\begin{array}{c}\text { No } \\
\text { addition }\end{array}$ & $\begin{array}{c}\mathrm{KCl} \\
1.50 \mathrm{~mm})\end{array}$ \\
\hline 0 & 32 & 56 & if & 4 \\
\hline 2 & 32 & 65 & () & +.4 \\
\hline 4 & 36 & 60 & 0 & 9.0 \\
\hline 8 & 35 & 70 & 1) & 8.2 \\
\hline 16 & 39 & 72 & 1 & 9.8 \\
\hline 32 & 40 & 82 & 0 & 13.5 \\
\hline 64 & 47 & 80 & 11 & 12.7 \\
\hline 128 & 49 & 94 & 11 & 10.7 \\
\hline
\end{tabular}

Note. Enzyme activity expressed in nmole/hr'mg.

ciencies associated with the accumulation of nucleosides $(1,2)$ and to the phosphorylation of potent nucleoside analogs with specific pharmacological properties. The easy availability of high specific activity isotopes and the use of ion exchange paper (3) provide a simple and rapid measure of these activities.

Previous investigators have noted the necessity of inhibiting deaminase enzymes to preserve the nucleoside substrate during assay (9-15). Indeed, our observations indicate that if this is not done in placental supernatant, then over $50 \%$ of deoxyadenosine or over $90 \%$ of deoxycytidine is degraded by deamination and phosphorolysis (Fig. 1). A valid assay can be achieved. if adenosine deaminase or cytidine deaminase is inhibited. However, it remains critical to make a definitive identification of the nucleoside kinase product at the time the assay is established. This assures that the anion exchange paper will bind an established nucleotide product and not an artifact.

Our data suggest other important considerations related to nucleoside kinase assays. Uniformly labeled nucleosides should be avoided in kinase assays (6-8), as a result of the potential production of labeled ribose-1phosphate or deoxyribose-1-phosphate. These compounds behave like nucleotides in chromatography systems and on anion exchange paper. We have also found that GTP doubles the assayable deoxyadenosine and adenosine kinase in crude placental cytosol. The mechanism for the increased activity of deoxyadenosine kinase is related to the production of an inhibitory concentration of adenosine from ATP in crude tissue extracts. In contrast, GTP is the preferred phosphate donor for adenosine kinase not only in crude extracts but even when this enzyme has been highly purified $(22,25,26)$. In addition, potassium was an essential cofactor 
for deoxyadenosine kinase, an activator of adenosine kinase, and inert for deoxycytidine kinase. Finally, a sulfhydryl reducing reagent was absolutely required for the measurement of deoxycytidine and deoxyadenosine kinase.

Using the modified conditions described in our experiments, assays of adenosine kinase, deoxyadenosine kinase, and deoxycytidine kinase are linear with time and protein. The current approach has proven useful to one of our colleagues, who was able to achieve linear nucleoside kinase assays in extracts from cultured human $B$ lymphoblasts and $T$ lymphoblasts after previous difficulties in achieving a valid assay (27).

\section{SUMMARY}

The measurements of deoxyadenosine kinase, adenosine kinase, and deoxycytidine kinase were examined in human placental cytosol to achieve a valid and reliable assay linear with time and protein. Our studies confirm the need to inhibit deaminase enzymes, since deoxyadenosine and deoxycytidine undergo extensive deamination and phosphorolysis. The use of a uniformly labeled nucleoside substrate introduced an artifact because the chromatographic behavior of the deoxyribose-1-phosphate, formed during the assay, was difficult to distinguish from the deoxynucleoside phosphate product. Accurate product identification was also essential. Finally, the substitution of GTP in place of ATP as the phosphate donor, the addition of a sulfhydryl reducing agent and a monovalent cation need to be considered when an assay is optimized.

The use of these methods have lead to valid assays in placental cytosol that are linear with time and protein. Consideration of these important principles are necessary when establishing a valid and reliable nucleoside kinase assay in a crude tissue preparation.

\section{ACKNOWLEDGMENTS}

The authors wish to thank the nurses and patients from the delivery room of Women's Hospital for providing fresh placenta, Bonnie Taylor for carrying out the high-pressure liquid chromatography, and Linda Allen and Jo Ellen Ivacko for typing this manuscript.

\section{REFERENCES}

1. Coleman, M. S., Donofrio, J., Hutton, J. H., Hahn, O., Daoud, A., Lampkin, B., and Dyminski, J., J. Biol. Chem. 253, 1619 (1978).

2. Cohen, H., Hirschhorn, R., Horowitz, S., Rubinstein, A., Polmar, S. H., Hong, R., and Martin, D. W., Jr., Proc. Nat. Acad. Sci. USA 75, 472 (1978).

3. Ives, D. H., Durham, J. P., and Tucker, V. S., Anal. Biochem. 28, 192 (1969).

4. Andres, C. M., and Fox, I. H., J. Biol. Chem. 254, 11388 (1979).

5. Palella, T. D., Andres, C. M., and Fox, 1. H., J. Biol. Chem. 255, 5264 (1980).

6. Meyers, B. B., and Kreis, W., Arch. Biochem. Biophys. 177, 10 (1976).

7. Meyers, B. B., and Kreis, W., Cancer Res. 38, 1105 (1978).

8. Mollgaard, H., J. Biol. Chem. 255, 8216 (1980). 
9. Coleman, C. N.. Stoller, R. G., Drake, J. C.. and Chabner, B. A.. Blood 46, 791 (1975).

10. Leung, W., Dubbs, D. R., Trkula, D.. and Kit, S., J. Virol. 16, 488 (1975).

11. Carson, D. A., Kaye. J., and Seegmiller, J. E.. Proc. Nat. Acad. Sci. USA 74, 5677 (1977).

12. Ives, D. H., and Wang, S. -M., Methods Enzymol. 61, 337 (1978).

13. Ullman, B., Gudas, L. J.. Cohen, A., and Martin, D. W.. Jr.. Cell 14, 365 (1978).

14. Verhoef, V., Sarup, J., and Fridland, A., Cancer Res. 41, 4478 (1981).

15. Diebel, M.. Coleman. M. S., and Hilton, J., Biochem. Med. 25, 288 (1981),

16. Bradford, M., Anal. Biochem. 72, 248 (1976).

17. Streeter, D. G.. Simon, L. N., Robins, R. K., and Miller, J. P.. Biochemistry 13, 4543 (1974).

18. Krenitsky. T. A., Tuttle. J. V., Koszalka, G. W.. Chen, I. S.. Beacham. L. M.. III. Rideout, J. L., and Elion, G. B.. J. Biol. Chem. 251, 4055 (1976).

19. Wan, C. W., and Mak. T. W., Cancer Res. 38, 2768 (1978).

20. Miller, R. L., Adamczyk. D. L., and Miller, W. H., J. Biol. Chem. 254, 2339 (1979).

21. Harkrader, R. J., Jackson, R. C., Ross, D. A., and Weber. G.. Biochem. Biophy, Res. Commun. 96, 1633 (1980).

22. Yamada, Y., Goto, H., and Ogasawara, N., Biochim. Biophys. Acta 660, 36 (1981).

23. Durham, J. P., and Ives. D. H., J. Biol. Chem. 245, 2276 (1970).

24. Cheng, Y., Domin, B., and Lee, L., Biochim. Biophys. Acta 481, 481 (1977).

25. Yamada, Y.. Goto. H., and Ogasawara, N.. Biochim. Biophys. Acta. 616, 199 (1980).

26. Chang, C. Brockman, R. W., and Bennett, I.. I... J. Biol. Chem. 225, 2366 (1980)

27. Mitchell, B., personal communication. 